\title{
Physiological quality of seed and seedling performance of crambe genotypes under water stress
}

\author{
Fernando H. B. Machado ${ }^{1}$, Andréia M. S. de S. David ${ }^{1}$, Lucas V. S. Cangussú ${ }^{1}$, \\ Josiane C. Figueiredo ${ }^{1} \&$ Hugo T. R. Amaro ${ }^{1}$
} ${ }^{1}$ Universidade Estadual de Montes Claros/Departamento de Ciências Agrárias. Janaúba, MG. E-mail: fernandobogard@yahoo.com.br; andreia.david@unimontes.br;
lucasvscagro@hotmail.com (Corresponding author); josycantuaria@yahoo.com.br; htiagoamaro@yahoo.com.br

Key words:

Crambe abyssinica Hoechst germination polyethylene glycol

\begin{abstract}
A B S T R A C T
Water stress is a condition that causes physiological changes in different species and even genotypes of the same species. One of the osmotic agents most used to simulate this condition is polyethylene glycol 6000. The aim of this study was to evaluate the effects of water stress on the physiological quality of seeds and performance of seedlings of crambe genotypes. A completely randomized design was used, in a factorial scheme with two genotypes (one cultivar and one line) and five osmotic potentials simulated with aqueous solutions of polyethylene glycol 6000 (control $=0,-0.25,-0.50,-1.0,-1.50 \mathrm{MPa}$ ), with four replicates of 50 seeds per treatment. The effects of the treatments were evaluated by means of germination, first count, germination speed index and fresh and dry matter of seedlings. The physiological quality of seeds and the performance of crambe seedlings are negatively affected under water stress from - $0.25 \mathrm{MPa}$ on. Seeds of the genotype FMSCR 1101 have greater tolerance to drought stress, regardless of the osmotic potential used.
\end{abstract}

\section{Palavras-chave:}

Crambe abyssinica Hoechst germinação polietilenoglicol

\section{Qualidade fisiológica de sementes e desempenho de plântulas de genótipos de crambe sob estresse hídrico}

\begin{abstract}
R E S U M O
O estresse hídrico é uma condição que provoca alterações fisiológicas em diversas espécies e até mesmo em genótipos de uma mesma espécie. Um dos agentes osmóticos mais utilizados para simular esta condição é o polietilenoglicol 6000. Objetivou-se, com este trabalho avaliar os efeitos do estresse hídrico na qualidade fisiológica de sementes e no desempenho de plântulas de genótipos de crambe. Utilizou-se o delineamento experimental inteiramente casualizado em esquema fatorial com dois genótipos (uma cultivar e uma linhagem) e cinco potenciais osmóticos simulados com soluções aquosas de polietilenoglicol 6000 (testemunha $=0 ;-0,25$; $-0,50 ;-1,0 ;-1,50 \mathrm{MPa}$ ), em quatro repetições de 50 sementes por tratamento. Os efeitos dos tratamentos foram avaliados por meio dos testes de germinação, primeira contagem de germinação, índice de velocidade de germinação, matéria fresca e matéria seca de plântulas. A qualidade fisiológica das sementes e o desempenho das plântulas de crambe são afetados negativamente sob estresse hídrico a partir de -0,25 MPa. Sementes do genótipo FMSCR 1101 apresentam maior tolerância ao estresse hídrico, independente do potencial osmótico utilizado.
\end{abstract}




\section{INTRODUCTION}

Crambe (Crambe abyssinica Hochst. - Brassicaceae) has its origins in the Mediterranean region. Since its seeds have considerable oil content, approximately $38 \%$, they can be used for the production of cosmetics and especially biodiesel (Pitol et al., 2010). Still according to these authors, it is an annual herbaceous species that has taproot system that, when deep into the soil, provides the plant with drought tolerance.

The physiology of plants varies considerably under water stress during their development, because it decreases emergence speed and seedlings development, affecting agronomic components, such as size and weight of seeds (Donaldson, 1996). Additionally, genotypes of a same species may exhibit different behavior when subjected to water deficit conditions.

Many methodologies have been recommended to identify genotypes more adapted to the low water availability in the soil (Hadas, 1976; Campos \& Assunção, 1990). One of the products most used to simulate osmotic stress in plants is polyethylene glycol 6000, which is a chemically inert and non-toxic osmotic agent that simulates low water potentials without being absorbed by the seeds, due to the large size of its molecules (Villela et al., 1991; Martinelli-Semene et al., 2000).

Thus, studies must be conducted to determine the minimum and optimum conditions of osmotic potential, allowing to identify the genotypes most adapted to water scarcity conditions in the semi-arid region of Minas Gerais, Brazil. Based on this context, this study aimed to evaluate the effects of water stress on the physiological quality of seeds and performance of seedlings of crambe genotypes.

\section{Material AND Methods}

The experiment was carried out at the laboratory of seed analysis of the State University of Montes Claros (UNIMONTES), campus of Janaúba, MG, Brazil, from January to March 2015, using seeds of two crambe genotypes from the 2014 season, provided by the Mato Grosso do Sul Foundation.

The experimental design was completely randomized in a $2 \times 5$ factorial scheme, with four replicates of 50 seeds. The treatments consisted of two crambe genotypes (FMS Brilhante and FMSCR 1101) and five levels of water deficit (control $=0,-0.25,-0.50,-1.0,-1.50 \mathrm{MPa}$ ) obtained from aqueous solutions of polyethylene glycol 6000 (PEG 6000), prepared according to the specifications of Villela et al. (1991).

For the germination test, the seeds were disinfected after immersion, for $2 \mathrm{~min}$, in a $2 \%$ sodium hypochlorite solution and then washed in running water for $5 \mathrm{~min}$. Subsequently, four replicates of 50 seeds were distributed in transparent plastic boxes $(11 \times 11 \times 3 \mathrm{~cm})$, on two Germitest paper sheets, moistened with $10 \mathrm{~mL}$ of solution for all water potentials of PEG 6000, as previously described. The plastic boxes containing the seeds were placed in a BOD chamber, with constant temperature of $20^{\circ} \mathrm{C}$. The evaluations were performed on the fourth (first count of germination) and seventh days after sowing, and the results were expressed in percentage of normal seedlings, according to the criteria established by Brasil (2009).

The germination speed index was obtained by the sum of the number of seeds germinated every day, divided by the number of days elapsed from sowing to germination, according to Eq.1, described by Maguire (1962).

$$
\mathrm{GSI}=\frac{\mathrm{G} 1}{\mathrm{~N} 1}+\frac{\mathrm{G} 2}{\mathrm{~N} 2}+\ldots+\frac{\mathrm{Gn}}{\mathrm{Nn}}
$$

where:

GSI - germination speed index;

G1, G2, G3, ..., Gn - number of seedlings in the first, second, third and last counts; and,

$\mathrm{N} 1, \mathrm{~N} 2, \mathrm{~N} 3, \ldots, \mathrm{Nn}$ - number of days from sowing to the first, second, third and last counts.

The normal seedlings resulting from the germination test were used for the determination of seedlings fresh matter, by weighing on a precision scale $(0.0001 \mathrm{~g})$, and the results were expressed in grams per replicate. Later, the obtained seedlings were placed in paper bags and dried in a forced-air oven at 65 ${ }^{\circ} \mathrm{C}$ for $72 \mathrm{~h}$ for the determination of dry matter, in grams per replicate.

The statistical program Sisvar (Ferreira, 2011) was used to evaluate the results, which were subjected to analysis of variance at 0.05 probability level and then regression analysis. When significant, the effects of the genotypes were studied using the F test at 0.05 significance level, whereas the effects of the osmotic potentials were studied using regression analysis, selecting the models most adequate to represent them based on the biological behavior, significance of the model coefficients and coefficient of determination $\left(\mathrm{R}^{2}\right)$.

\section{RESUlts AND Discussion}

The results of the analysis of variance showed that, except for seedling dry matter, the other variables were significantly influenced by the interaction between the factors genotypes and osmotic potentials.

The mean results of germination, first count of germination, germination speed index and seedling fresh matter of the crambe genotypes, at each level of osmotic potential of PEG 6000, are presented in Table 1.

Initially $(0.0 \mathrm{MPa})$, the seeds of both genotypes exhibited high percentage of germination (superior to $80 \%$ ). In addition, up to the potential of $-0.50 \mathrm{MPa}$, the germination of the studied genotypes was similar. For the genotype FMSCR 1101, the germination was null at the osmotic potential of -1.5 $\mathrm{MPa}$, while for FMS Brilhante there was no germination at the osmotic potential of $-1.00 \mathrm{MPa}$ induced by the PEG 6000 .

The results of vigor obtained in the first count of germination were more affected by the different levels of osmotic potential compared with germination, as the concentrations of the PEG 6000 solutions increased. Similar results were found by Ávila et al. (2007), who observed reduction in the percentage of normal seedlings in the first count of germination of canola seeds, as the levels of osmotic potential became more negative. The 
Table 1. Germination, first count of germination, germination speed index and seedling fresh matter of crambe (Crambe abyssinica Hochst.) genotypes subjected to different levels of water stress

\begin{tabular}{lccccc}
\hline \multirow{2}{*}{ Genotypes } & \multicolumn{5}{c}{ Osmotic potentials (MPa) } \\
\cline { 2 - 6 } & $\mathbf{0}$ & $\mathbf{- 0 . 2 5}$ & $\mathbf{- 0 . 5 0}$ & $\mathbf{- 1 . 0 0}$ & $\mathbf{- 1 . 5 0}$ \\
FMSCR 1101 & $84 \mathrm{a}$ & $79 \mathrm{a}$ & $43 \mathrm{a}$ & $12 \mathrm{a}$ & $0 \mathrm{a}$ \\
FMS Brilhante & $88 \mathrm{a}$ & $69 \mathrm{a}$ & $39 \mathrm{a}$ & $0 \mathrm{~b}$ & $0 \mathrm{a}$ \\
\hline \multicolumn{5}{c}{ First count of germination (\%) } \\
FMSCR 1101 & $61 \mathrm{a}$ & $51 \mathrm{a}$ & $30 \mathrm{a}$ & $6.0 \mathrm{a}$ & $0.0 \mathrm{a}$ \\
FMS Brilhante & $65 \mathrm{a}$ & $43 \mathrm{~b}$ & $10 \mathrm{~b}$ & $0.0 \mathrm{~b}$ & $0.0 \mathrm{a}$ \\
\hline \multicolumn{7}{c}{ Germination speed index } \\
FMSCR 1101 & $16.7 \mathrm{~b}$ & $12.4 \mathrm{a}$ & $5.2 \mathrm{a}$ & $1.6 \mathrm{a}$ & $0.0 \mathrm{a}$ \\
FMS Brilhante & $19.3 \mathrm{a}$ & $11.6 \mathrm{a}$ & $3.7 \mathrm{~b}$ & $0.0 \mathrm{~b}$ & $0.0 \mathrm{a}$ \\
\hline \multicolumn{5}{c}{ Seedling fresh matter (g) } \\
FMSCR 1101 & $1.79 \mathrm{a}$ & $1.43 \mathrm{a}$ & $1.37 \mathrm{a}$ & $0.94 \mathrm{a}$ & $0.00 \mathrm{a}$ \\
FMS Brilhante & $1.26 \mathrm{~b}$ & $1.16 \mathrm{~b}$ & $0.82 \mathrm{~b}$ & $0.00 \mathrm{~b}$ & $0.00 \mathrm{a}$ \\
\hline Means followed by the same letter in the column do not differ by F test at 0.05 significance level
\end{tabular}

first count of germination is a simple test of vigor, performed simultaneously to the germination test and based on the assumption that more vigorous seeds germinate faster (Abud et al., 2013).

It is observed that, in environment without water stress (0.0 MPa), there was no statistical difference for the first count of germination between the genotypes (Table 1). However, at osmotic potentials of $-0.25,-0.50$ and $-1.0 \mathrm{MPa}$, the genotypes differed and the highest values were obtained by the FMSCR 1101.

Regarding the germination speed index, the seeds of the genotype FMS Brilhante showed higher values at the osmotic potential of $0.0 \mathrm{MPa}$. At the levels of -0.25 and $-0.50 \mathrm{MPa}$, the genotype FMSCR 1101 was more tolerant, while at the highest concentration $(-1.50 \mathrm{MPa})$ the values were null for both genotypes.

In general, for both genotypes, the effect of reduction in the vigor of the first count of germination and in the germination speed index was evident from the potential of $-0.25 \mathrm{MPa}$ on, while at the potential of -1.0 MPa there was no germination of FMSCR 1101 seeds. For the genotype FMS Brilhante, germination was null at the osmotic potential of $-1.00 \mathrm{MPa}$ (Table 1).

Ávila et al. (2007) observed that, whenever the osmotic potential decreased, the number of days for initial germination of canola seeds increased. Still according to these authors, one of the effects of water stress is the delay in the beginning of seed germination. Dell'Aquila (1992) claims that the ability of the embryo to synthesize new proteins during the germination can be an important process sensitive to hydration, because the protein synthesis in the embryonic tissues is reduced with the increase in the water deficit.

The germination of FMSCR 1101 seeds observed at the osmotic potential of $-1.0 \mathrm{MPa}$ can be explained by the fact that the species becomes dependent on the genetic material, i.e., the factor genotype will be determinant with respect to the tolerance or not to the water deficit present in the soil, as mentioned by Martinelli-Seneme et al. (2000).

For the variable seedling fresh matter (Table 1), at the potentials of $0.0,-0.25,-0.50$ and $-1.0 \mathrm{MPa}$, the highest accumulations of fresh matter were observed in seedlings of the genotype FMSCR 1101. In addition, it is noted that, at the potential of $-1.0 \mathrm{MPa}$, the fresh matter accumulation was null for the genotype FMS Brilhante. However, at higher concentrations $(-1.50 \mathrm{MPa})$, the values were null for both genotypes.

The water restriction acts by reducing the speed of the physiological and biochemical processes and, therefore, crambe seedlings under conditions of low moisture exhibit lower growth, thus lower accumulations of fresh matter (Hadas, 1976).

The results of germination fitted to a linear regression equation, with reduction in the germination percentage of the studied genotypes proportional to the decrease in the osmotic potential (Figure 1).

The behavior of the variables as a function of the levels of osmotic potential of PEG 6000, for each genotype, is illustrated in Figures 2 and 3.

For the genotype FMSCR 1101, there was no germination when subjected to the potential of $-1.5 \mathrm{MPa}$, whereas in the genotype FMS Brilhante, which was more affected by the water stress, germination was null at the potential of -1.00 MPa. These results corroborate those found by Teixeira et al. (2011), who observed that the reduction in the osmotic potential of the soaking solution caused decreases in the germination of crambe seeds. Medeiros et al. (2015) also observed significant reduction in the germination of sesame seeds from the water potential of $-0.2 \mathrm{MPa}$ on, reaching null values at the osmotic potential of -1.0 MPa.

Similarly, Pereira \& Lopes (2011) observed reduction in the germination of jatropha seeds when subjected to successive reduction of the osmotic potential with polyethylene glycol. Teixeira et al. (2011) also found values close to zero in the germination of crambe seeds at osmotic potentials lower than -1.0 MPa induced by PEG 6000. For canola, Santos et al. (2012) observed that the reduction of water availability in the substrate from - 0.3 MPa on significantly reduced seed germination.

The decrease in germination can also be attributed to the lower mobilization of reserves, lower synthesis and enzymatic activities or changes in cell turgor (Bewley et al., 2013).

Regarding the vigor of the seeds, evaluated by the tests of first count of germination and germination speed index (Figures $2 \mathrm{~A}$ and $2 \mathrm{~B}$ ), it is observed that in both genotypes

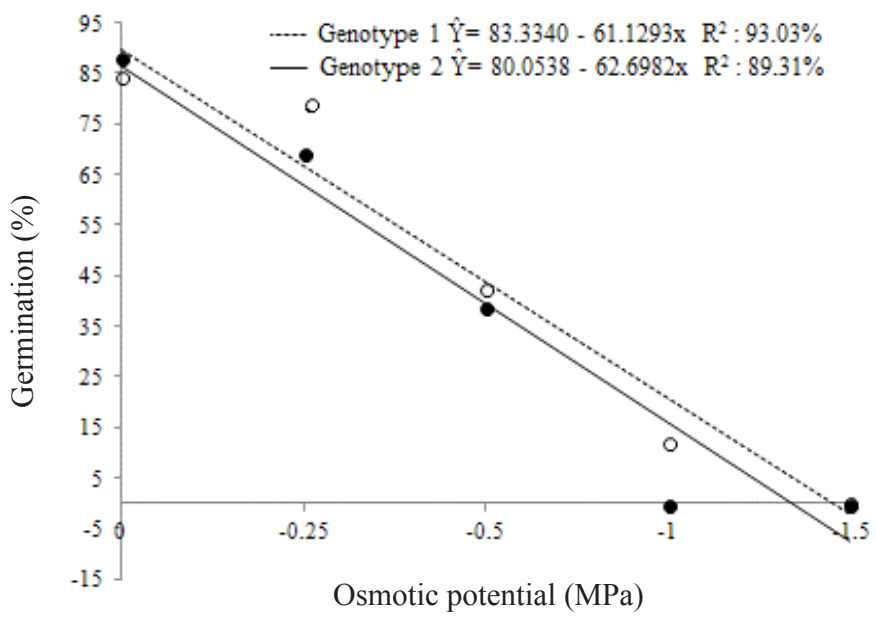

Figure 1. Germination of seeds of crambe (Crambe abyssinica Hochst.) genotypes subjected to different levels of water stress 

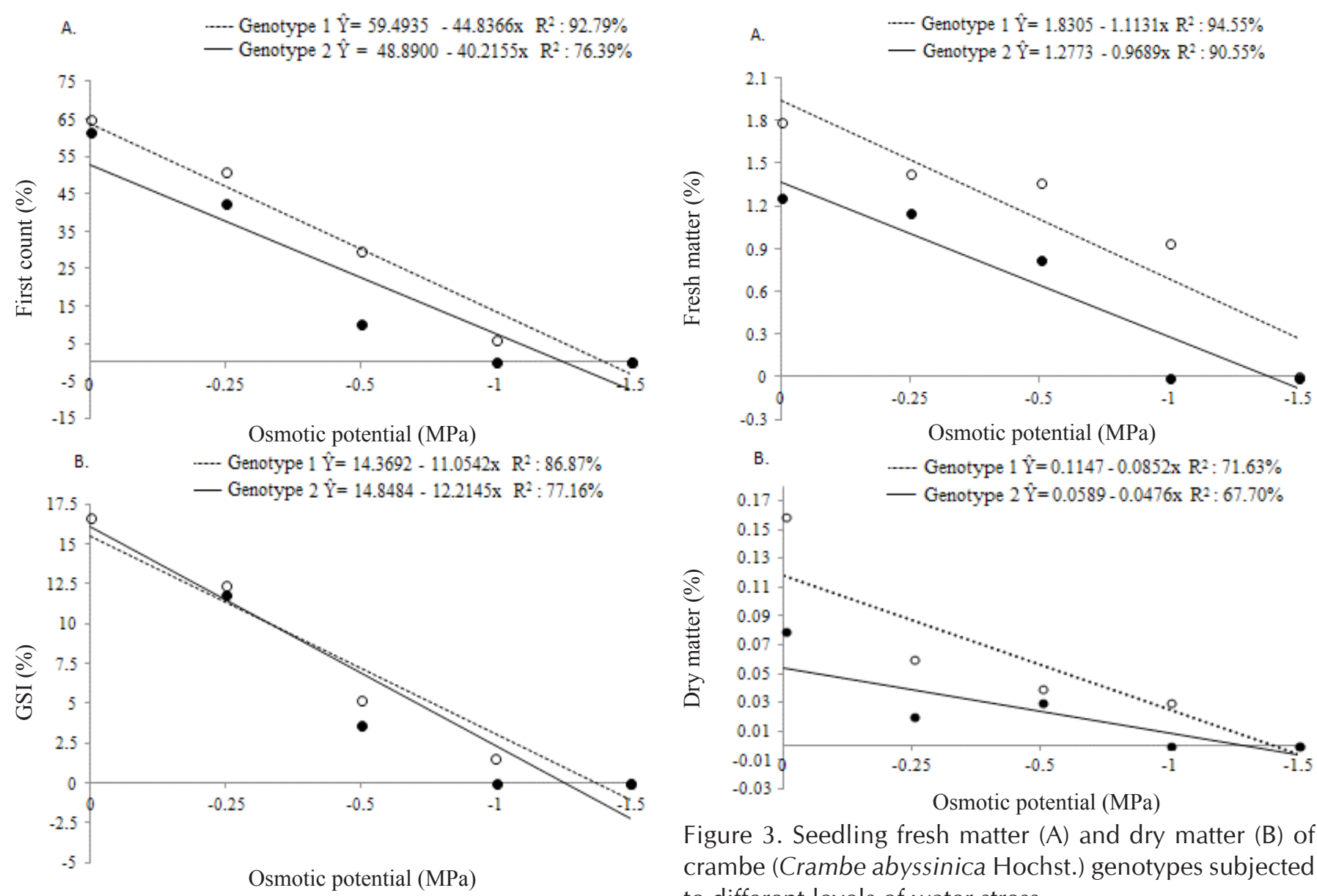

Figure 2. First count of germination $(\mathrm{A})$ and germination speed index - GSI (B) of seeds of crambe (Crambe abyssinica Hochst.) genotypes subjected to water stress

the increase in water deficit, through the increment of PEG 6000 concentrations in the solution of the substrate, was responsible for significant decreases in the germination speed. Higher values of germination speed index are based on the speed and uniformity of development of the seedlings of the sample, reflecting in higher vigor index. Thus, it is noted that the reduction of the osmotic potential of the solution of the substrate made the germination of crambe seeds slower and irregularly distributed over time, negatively influencing their vigor. Masetto et al. (2011) also observed increasing reduction in the formation of normal seedlings in the first count of germination of crambe seeds, as the water availability of the substrate decreased, regardless of the water content of the seeds.

According to Oliveira \& Gomes Filho (2009), water stress can decrease both the percentage and speed of germination, with large variation of responses among the species. Thus, the capacity of the seeds of some species to germinate under water stress conditions guarantees some ecological advantages over the others that are sensitive to drought (Martins et al., 2014).

Bruni \& Leopold (1992) suggest that the reduction of the first count of germination and emergence speed is caused by the water deficit, which leads to the progressive loss of protoplasmic turgor and increase in the concentration of solutes. These effects initially result in a disorder of the cell function and, ultimately, in damages to the system of biomembranes.

Figure 3. Seedling fresh matter (A) and dry matter (B) of crambe (Crambe abyssinica Hochst.) genotypes subjected to different levels of water stress

The accumulation of fresh and dry matter in the seedlings of crambe genotypes decreased with the reduction in the osmotic potential, as illustrated in Figures $3 \mathrm{~A}$ and $3 \mathrm{~B}$. This reduction in biomass can be explained by the decrease in the metabolism of the seeds due to the lower water availability for digestion of the reserves and translocation of metabolized products (Bewley \& Black, 1994).

Decreases in fresh matter produced under water stress are constantly observed, since water stress induces the reduction in leaf water potential, which leads to the regulation of genes related to the photosynthesis and has, as a consequence, the closure of the stomata and reduction in $\mathrm{CO}_{2}$ availability, with consequent reduction in the production of mass of the plant (Osakabe et al., 2014). As observed in the present study, there are levels of osmotic potential that cause reduction in the physiological performance of the seeds, which become critical for both germination and vigor, and the development of the seedlings.

The results demonstrate the importance of the evaluation of water potentials in the substrate considered as critical for seed germination and growth of crambe seedlings, besides the necessity of a careful selection of genotypes that have tolerance to the water deficit conditions in the environment. Therefore, these conditions of water availability cause the seeds to require a higher number of days to germinate, which is not desirable under field conditions, because the delay in germination predisposes the seeds to a greater exposure to the action of pathogens and attacks of insects and pests. Thus, the relationship between the water potential of the environment 
and the time of germination is an important variable, especially in regions where the soil surface is dry.

\section{Conclusions}

1. Seed physiological quality and seedling performance of crambe are negatively affected under water stress from -0.25 MPa on.

2. Seeds of the genotype FMSCR 1101 have higher tolerance to water stress, regardless of the osmotic potential used.

\section{Literature Cited}

Abud, H. F.; Araújo, E. F.; Araújo, R. F.; Araújo, A. V.; Pinto, C. M. F. Qualidade fisiológica de sementes das pimentas malagueta e biquinho durante a ontogênese. Pesquisa Agropecuária Brasileira, v.48, p.15461553, 2013. http://dx.doi.org/10.1590/ S0100-204X2013001200003.

Ávila, M. R.; Braccini, A. L.; Scapim, C. A.; Fagliari, J. R.; Santos, J. L. Influência do estresse hídrico simulado com manitol na germinação de sementes e crescimento de plântulas de canola. Revista Brasileira de Sementes, v.29, p.98-106, 2007. http://dx.doi. org/10.1590/S0101-31222007000100014.

Bewley, J. D.; Black, M. Seeds: Physiology of development and germination. 2.ed. New York: Springer 1994. 445p.

Bewley, J. D.; Bradford, K. J.; Hilhorst, H. W. M.; Nonogaki, H. Seeds: Physiology of development, germination and dormancy. 3.ed. New York: Springer, 2013. 392p.

Brasil. Ministério da Agricultura, Pecuária e Abastecimento. Secretaria de Defesa Agropecuária. Regras para análise de sementes. Brasília: MAPA, 2009. 395p.

Bruni, F. B.; Leopold, A. C. Cytoplasmic glass formation in maize embryos. Seed Science Research, v.2, p.251-253, 1992.

Campos, I. S.; Assunção, M. V. Efeitos do cloreto de sódio na germinação e vigor de plântulas de arroz. Pesquisa Agropecuária Brasileira, v.25, p.837-843, 1990.

Dell'Aquila, A. Water uptake and protein synthesis in germinating wheat embryos under the osmotic stress of polyethylene glycol. Annals of Botany, v.69, p.167-171,1992.

Donaldson, E. Crop traits for water stress tolerance. American Journal of Alternative Agriculture, v.11, p.89-94, 1996.

Ferreira, D. F. Sisvar: A computer statistical analysis system. Ciência e Agrotecnologia, v.35, p.1039-1042, 2011. http://dx.doi. org/10.1590/S1413-70542011000600001

Hadas, A. Water uptake and germination of leguminous seeds under changing external water potencial in osmotic solution. Journal Experimental Botany, v.27, p.480-489, 1976.
Maguire, J. D. Speed of germination aid in selection and evaluation for seedling emergence and vigor. Crop Science, v.2, p.176-77, 1962.

Martinelli-Seneme, A.; Martins, C. C.; Nakagawa, J. Germinação de milho cv. AL-34 em função do tamanho da semente e do potencial hídrico do substrato. Revista Brasileira de Sementes, v.22, p.131-138, 2000. http://dx.doi.org/10.17801/0101-3122/ rbs.v22n2p131-138

Martins, C. C.; Pereira, M. R. R.; Lopes, M. T. G. Germinação de sementes de eucalipto sob estresse hídrico e salino. Bioscience Journal, v.30, p.318-329, 2014.

Masetto, T. E.; Quadros, J. B.; Ribeiro, D. M.; Rezende, R. K. S.; Scalon, S. P. Q. Potencial hídrico do substrato e teor de água das sementes na germinação do crambe. Revista Brasileira de Sementes, v.33, p.511-519, 2011. http://dx.doi.org/10.1590/S010131222011000300014

Medeiros, D. S.; Alves, E. U.; Sena, D. V. dos A.; Silva, E. de O.; Araújo, L. R. Desempenho fisiológico de sementes de gergelim submetidas a estresse hídrico em diferentes temperaturas. Semina: Ciências Agrárias, v.36, p.3069-3076, 2015. http://dx.doi.org/10.5433/16790359.2015v36n5p3069

Oliveira, A. B.; Gomes Filho, E. Germinação e vigor de sementes de sorgo forrageiro sob estresse hídrico e salino. Revista Brasileira de Sementes, v.31, p.48-56, 2009. http://dx.doi.org/10.1590/S010131222009000300005

Osakabe, Y.; Osakabe, K.; Shinozaki, K.; Tran, L. S. P. Response of plants to water stress. Frontier in Plant Science, v.5, p.1-8, 2014. http://dx.doi.org/10.3389/fpls.2014.00086

Pereira, M. D.; Lopes, J. C. Germinação e desenvolvimento de plântulas de pinhão manso sob condições de estresse hídrico simulado. Semina: Ciências Agrárias, v.32, p.1837-1842, 2011. http://dx.doi.org/10.5433/1679-0359.2011v32Suplp1837

Pitol, C.; Brochi, D. L.; Roscoe, R. Tecnologia e produção: Crambe 2010. Aracajú: Fundação MS, 2010.60p.

Santos, A.; Scalon, S. P. Q.; Masetto, T. E.; Nunes, D. P. Disponibilidades hídricas do substrato na qualidade fisiológica de sementes de canola com diferentes teores de água. Agrarian, v.5, p.356-364, 2012.

Teixeira, R. N.; Toledo, M. Z.; Ferreira, G.; Cavariani, C.; Samir, P. S. Germinação e vigor de sementes de crambe sob estresse hídrico. Irriga, v.16, p.42-51, 2011. http://dx.doi.org/10.15809/ irriga.2011v16n1p42

Villela, F. A.; Doni Filho, L.; Sequeira, E. L. Tabela de potencial osmótico em função da concentração de polietileno glicol 6000 e da temperatura. Pesquisa Agropecuária Brasileira, v.26, p.19571968, 1991. 